\title{
Molecular detection of Bartonella spp. in deer ked (Lipoptena cervi) in Poland
}

\author{
Tomasz Szewczyk*, Joanna Werszko, Żaneta Steiner-Bogdaszewska, Witold Jeżewski, Zdzisław Laskowski \\ and Grzegorz Karbowiak
}

\begin{abstract}
Background: The bacteria of the genus Bartonella are obligate parasites of vertebrates. Their distribution range covers almost the entire world from America, Europe, Asia to Africa and Australia. Some species of Bartonella are pathogenic for humans. Their main vectors are blood-sucking arthropods such as fleas, ticks and blood-feeding flies. One such dipteran able to transfer vector-borne pathogens is the deer ked (Lipoptena cervi) of the family Hippoboscidae. This species acts as a transmitter of Bartonella spp. in cervid hosts in Europe.

Methods: In the present study, 217 specimens of deer ked (Lipoptena cervi) were collected from 26 red deer (Cervus elaphus) hunted in January 2014. A short fragment (333 bp) of the rpoB gene was used as a marker to identify Bartonella spp. in deer ked tissue by PCR test. A longer fragment $(850 \mathrm{bp})$ of the rpoB gene was amplified from 21 of the positive samples, sequenced and used for phylogenetic analysis.

Results: The overall prevalence of Lipoptena cervi infection with Bartonella spp. was 75.12\% (163/217); 86.67\% (104/ 120) of females and 60.82\% (59/97) of males collected from red deer hunted in the Strzałowo Forest District in Poland $\left(53^{\circ} 45^{\prime} 57.03^{\prime \prime} \mathrm{N}, 2^{\circ} 25^{\prime} 17.79^{\prime \prime} \mathrm{E}\right)$ were infected. The nucleotide sequences from 14 isolates (Bartonella sp. 1) showed close similarity to Bartonella schoenbuchensis isolated from moose blood from Sweden (GenBank: KB915628) and human blood from France (GenBank: HG977196); Bartonella sp. 2 (5 isolates) and Bartonella sp. 3 (one isolate) were similar to Bartonella sp. from Japanese sika deer (GenBank: AB703149), and Bartonella sp. 4 (one isolate) was almost identical to Bartonella sp. isolated from Japanese sika deer from Japan (GenBank: AB703146).

Conclusions: To the best of our knowledge, this is the first report to confirm the presence of Bartonella spp. in deer keds (Lipoptena cervi) in Poland by molecular methods. Bartonella sp. 1 isolates were most closely related to B. schoenbuchensis isolated from moose from Sweden and human blood from France. The rest of our isolates (Bartonella spp. 2-4) were similar to Bartonella spp. isolated from Japanese sika deer from Japan.
\end{abstract}

Keywords: Bartonella spp., Bartonella schoenbuchensis, Lipoptena cervi, Cervus elaphus

\section{Background}

The genus Bartonella comprises small, Gram-negative bacteria which act as obligate intracellular parasites of vertebrates. About 30 species, as well as three subspecies, have been described [1]. The zoonotic reservoir for some Bartonella species (B. schoenbuchensis, B. baciliformis and B. quintana), is composed of wild mammals, which usually only possess asymptomatic bacteraemia. The prevalence of bacteremia in wild animals is often very high, ranging from 50 to $95 \%$ in selected rodent

\footnotetext{
* Correspondence: t.szewczyk86@gmail.com

Witold Stefański Institute of Parasitology, Polish Academy of Sciences, Twarda 51/55, 00-818 Warsaw, Poland
}

(c) The Author(s). 2017 Open Access This article is distributed under the terms of the Creative Commons Attribution 4.0 International License (http://creativecommons.org/licenses/by/4.0/), which permits unrestricted use, distribution, and reproduction in any medium, provided you give appropriate credit to the original author(s) and the source, provide a link to the Creative Commons license, and indicate if changes were made. The Creative Commons Public Domain Dedication waiver (http://creativecommons.org/publicdomain/zero/1.0/) applies to the data made available in this article, unless otherwise stated. on the season [3]. As the reservoir hosts include a wide range of wild mammals, including typically ruminants, rodents and carnivores, the infections are easily spread and have been noted all over the world [2]. A good example is that of ruminant infections: Bartonella infection has been recorded in cattle in three different countries (Thailand, Guatemala and Georgia) and in buffalo (Bubalus bubalis) from Thailand [4]. The prevalence of Bartonella infection in these regions varies between 10 and $90 \%$. Similar investigations in Japan found no infection in cattle, but recorded a prevalence of Bartonella 
sp., 67.5\% in Honshu sika deer (Cervus nippon centralis) and $50 \%$ in Yezo sika deer (Cervus nippon yesoensis) [5].

Many Bartonella species are considered as human pathogens and causative agents of zoonotic diseases: $B$. bacilliformis, the agent of Carrion's disease and Verruga peruna is the chronic delayed stage of infection; $B$. quintana, the agent of trench fever and bacillary angiomatosis; $B$. henselae, the agent of cat scratch disease and of bacillary angiomatosis; $B$. clarridgeiae, B. elizabethae, $B$. vinsonii subsp. arupensis, B. vinsonii subsp. berkhoffii, $B$. alsatica, B. koehlerae and B. washoensis all cause endocarditis [6-8]. The symptoms of human bartonellosis vary with regard to the bacterial species and general condition of the patient; however, Bartonella infection most often manifests as various cardiovascular, neurological and rheumatologic conditions $[8,9]$.

Bartonellosis has been observed in humans throughout Europe, Asia and North America. One of the most important species is Bartonella schoenbuchensis, which is found in cattle, wild animals (such as the cervids) and humans [10-12]. It has been identified in wild living roe deer (Capreolus capreolus) in Germany [10], in cattle in France [11] and in humans; B. schoenbuchensis was first detected in France [12].

Bartonella are transmitted by blood-sucking arthropods, such as lice, flies, fleas and ticks, many of which are emerging pathogens of humans and animals [2, 13-15]. Dehio et al. [16] identified B. schoenbuchensis in Lipoptena cervi collected from red deer and roe deer. Halos et al. [14] reported the presence of Bartonella spp. in hippoboscide flies, and suggested that flies can be a vector for pathogens. Other authors $[14,17]$ have found Bartonella spp. in wingless adult deer keds.

Lipoptena cervi are blood-sucking parasites which belong to a highly specialized family of louse flies (Diptera: Hippoboscidae) [18, 19]. This species has a Palaearctic distribution and occurs in Europe, Asia and North America; it is known to be present in many countries, including Sweden, Norway, Japan, the USA and Finland [20, 21]. In America, it is regarded as an invasive species, believed to have been transported with deer from Europe in the 1800s. This species was identified in the USA for the first time during the Second World War [18]. In Europe, the most common blood-sucking ectoparasites of mammals belonging to this family are louse fly (Hippobosca equina), parasitizing cows and horses, deer keds (Lipoptena cervi and Lipoptena fortisetosa), parasitizing cervids, and sheep ked (Melophagus ovinus), which ectoparasites of sheep [22, 23]. Lipoptena fortisetosa in Europe could be introduced with Japanese sika deer (Cervus nippon). This cervids were introduced to England in 1860, and their number and range have since increased [24]. From England, the
Japanese sika deer were late introduced to Poland, where two species of Lipoptena have been identified: L. cervi and L. fortisetosa $[25,26]$.

Although the dominant hosts for two species of Lipoptena (L. cervi and L. fortisetosa) are cervids (Alces alces, Cervus elaphus, Cervus elaphus maral, Cervus nippon, Dama dama, Capreolus capreolus and Rangifer tarandus), the insects can attack a wide range of animals, including bovids (Ovis aries musimon, Bison bonasus, cattle, Capra aegagrus hircus and Ovis aries), carnivores (domestic dogs, Vulpes vulpes and Meles meles) and suids (Sus scrofa) [27]. The most important hosts of Lipoptena cervi in Europe are red deer (Cervus elaphus), roe deer (Capreolus capreolus), moose (Alces alces) and sika deer (Cervus nippon), while Japanese sika deer (Cervus nippon) are the predominate host in Japan, and white-tailed deer (Odocoileus virginianus), moose (Alces alces) and cattle (Bos taurus) in North America [21, 28, 29].

Generally, Lipoptena cervi is found swarming in large numbers on the host. Deer keds most frequently bite animal hosts; they can land on humans, but rarely bite in this case. Nevertheless, some authors have reported ked bites on humans [30,31].

The life-cycle of Lipoptena cervi begins with freeranging, winged adult deer keds that search for a suitable host (cervids). The winged deer keds usually suck blood from the host and mate; however, after landing on a host, they can crawl into the fur, shed their wings and become permanently associated with the host. The larvae develop up to stage 3 (L3) in the oviduct and are then deposited in the cervid fur as a white prepupa, which immediately starts to pupate. The fully developed pupa drops to the ground and remains there until August-September, when a new generation of winged adult deer keds can appear [29, 32, 33]. The female can produce to 20-25 larvae per year. Lipoptena cervi can overwinter on the host, and most deer keds can live to one year [34].

The winged adult Lipoptena cervi are attracted to large moving dark-colored objects when actively searching for a host [35]. Lipoptena cervi only fly for short distances and frequently attack accidental hosts such as humans or dogs [32].

Lipoptena cervi is a potential vector for other zoonotic pathogens, such as Anaplasma, Borrelia and Rickettsia species [36]. Korhonen et al. [37] showed for the first time transstadial transmission of Bartonella spp. in all development stages of deer ked (pupa, unfed adult winged deer ked). These data show vector competence for transmission of Bartonella spp. by Lipoptena cervi. In America, Bartonella sp. has been reported in Lipoptena cervi from white-tailed deer in Massachusetts [28], and in Lipoptena mazamae from white-tailed deer (Odocoileus virginianus) in Georgia and South Carolina (USA) [21]. Additionaly, it 
has also been suggested that wingless adults of $L$. mazamae, could be transmitted mechanically from female white-tailed deer to their offsprings [38]. Bartonella sp. has also been found in ticks (Ixodes ricinus) parasitizing roe deer in Poland [39].

The main goal of the study was detection of Bartonella spp. DNA in Lipoptena cervi by PCR test and verification of prevalence of this infection in adult wingless males and females. Molecular characterization of specimens of Bartonella spp. was done by analysis of partial (850 bp) rpoB gene sequences.

\section{Methods}

\section{Sample collection}

Living deer keds (Lipoptena cervi) were collected from 26 red deer (Cervus elaphus) hunted in January 2014 in the Strzałowo Forest District (53⒋ $\left.45^{\prime} 57.03^{\prime \prime} \mathrm{N}, 21^{\circ} 25^{\prime} 17.79^{\prime \prime} \mathrm{E}\right)$. After collection, all insects were preserved in $70 \%$ ethanol for further morphological and molecular processing. Identification of deer ked (L. cervi) species and sex were conducted using appropriate identification key [34] and molecular methods to confirm vector species.

\section{PCR and sequence analyses}

In the laboratory, the flies were removed from $70 \%$ alcohol and air-dried. The DNA was isolated from whole insect body using the AX Tissue Mini kit (A\&A Biotechnology, Gdynia, Poland) according to the manufacturer's protocol.

For PCR test the primers rpoR and rpoF were used. These primers amplify a $333 \mathrm{bp}$ fragment of the $r p o B$ gene of Bartonella spp. PCR reactions were conducted according to Paziewska et al. [40]. 21 of 163 positive samples were used to obtain a longer $(850 \mathrm{bp})$ fragment of the $r p o B$ gene with second set of primers $(1400 \mathrm{~F}$ and 2300R) [41] (Table 1).

PCR reactions were conducted in a $50 \mu \mathrm{l}$ reaction mixture containing $2 \mu \mathrm{l}$ of DNA template, $0.5 \mathrm{U}(0.1 \mu \mathrm{l})$ of RUN Taq polymerase (A\&A Biotechnology, Gdynia, Poland), $1 \mu \mathrm{l}$ of dNTPs (10 mM), $0.5 \mu \mathrm{l}$ of each primer $(20 \mathrm{mM})$, and $5 \mu \mathrm{l}$ of 10× Taq DNA polymerase buffer ( $\mathrm{pH}$ 8.6, $25 \mathrm{mM} \mathrm{MgCl}_{2}$ ). In the negative control, nuclease-free water was added to the PCR mix instead of the tested DNA.

DNA amplification (1400F/2300R) was performed using the DNA Engine PTC-200 Thermal Cycler

Table 1 List of primers sequences used in this study

\begin{tabular}{lll}
\hline Primer & Sequence (5'-3') & Reference \\
\hline L700F & AAAGTTAACCTGCCCACTGAT & This study \\
L1213R & CTGAACTCAGATCACGTAAGAAT & This study \\
rpoR & CGCATTATGGTCGTATTTGTCC & Paziewska et al. [40] \\
rpoF & GCACGATTYGCATCATCATTTCC & Paziewska et al. [40] \\
1400F & CGCATTGGCTTACTTCGTATG & Renesto et al. [41] \\
2300R & GTAGACTGATTAGAACGCTG & Renesto et al. [41] \\
\hline
\end{tabular}

(BioRad, Hercules, USA) using the following program: initial denaturation was performed at $94{ }^{\circ} \mathrm{C}$ for $5 \mathrm{~min}$, followed by 35 cycles of denaturation at $95{ }^{\circ} \mathrm{C}$ for $10 \mathrm{~s}$, annealing at $60{ }^{\circ} \mathrm{C}$ for $10 \mathrm{~s}$ and extension at $72{ }^{\circ} \mathrm{C}$ for 60 s. The final extension was performed at $72{ }^{\circ} \mathrm{C}$ for 7 min and then kept at $10{ }^{\circ} \mathrm{C}$ in a thermocycler.

The PCR products were visualized on a $1.0 \%$ agarose gel stained with ethidium bromide. Visualization was performed using ChemiDoc, MP Lab software (Imagine, BioRad, Hercules, USA). The resulting product was compared using the Nova 100 bp DNA Ladder Novazym (Poznań, Poland). The PCR amplicons were purified using a QIAEX II Gel Extraction Kit (Qiagen, Hilden, Germany), sequenced in both directions by Genomed (Poland) and contiguous sequences assembled using ContigExpress, Vector NTI Advance 11.0 (Invitrogen Life Technologies, New York, USA). The derived sequences were submitted to the GenBank database under the accession numbers MF580655-MF580675.

To confirm the morphological species determination of Lipoptena cervi, DNA from four specimens (positive in Bartonella spp. test and used in Bartonella isolate analysis), L700F and L1213R primers were used to amplify and sequence $412 \mathrm{bp}$ fragments of $16 \mathrm{~S}$ rDNA (Table 1 ).

In order to perform PCR amplification, the following mixture reaction was used: $4 \mu$ of DNA extract was added to $46 \mu \mathrm{l}$ of reaction mixture consisting of $0.1 \mu \mathrm{l}$ of Allegro Taq Polymerase DNA (5 U/ $\mu$ l) (Poznań, Poland), $0.5 \mu \mathrm{ldNTPs}(10 \mathrm{mM}), 1 \mu \mathrm{l}$ of each primer $(20 \mathrm{mM})$, $5 \mu \mathrm{l}$ of $10 \times$ Taq DNA polymerase buffer ( $\mathrm{pH} 8.6,25 \mathrm{mM}$ $\mathrm{MgCl}_{2}$ ), and $38.4 \mu \mathrm{l}$ of deionized water.

DNA amplification (L700F/L1213R) was performed using the DNA Engine PTC-200 Thermal Cycler (BioRad, Hercules, USA) using the following program:an initial denaturation was performed at $92{ }^{\circ} \mathrm{C}$ for $3 \mathrm{~min}$, followed by 35 cycles of denaturation at $95{ }^{\circ} \mathrm{C}$ for $10 \mathrm{~s}$, annealing at $60{ }^{\circ} \mathrm{C}$ for $10 \mathrm{~s}$ and extension at $72{ }^{\circ} \mathrm{C}$ for $30 \mathrm{~s}$. The final extension was performed at $72{ }^{\circ} \mathrm{C}$ for 5 min and then kept at $12{ }^{\circ} \mathrm{C}$ in a thermocycler.

\section{Phylogenetic analyses}

We used Bayesian inference (BI) analysis with MrBayes version 3.2 [42]. Analysis of partial $r p o B$ gene sequence data was based on an alignment of 804 bp (268 amino acids) using the GTR + I + G model. The GTR models were chosen on the basis of jModelTest version 2.1.4 $[43,44]$ using the Akaike information criterion.

\section{Results}

In total, 217 deer keds were collected from 26 red deer (Cervus elaphus). All insects were identified as Lipoptena cervi using morphological features [34]. The prevalence of Bartonella spp. infection was $75.12 \%$ (163/217) by PCR test. In the tested group of $L$. cervi, a greater 
proportion of females $(86.67 \%)$ was found to be positive for Bartonella spp. than males (60.82\%).

\section{PCR, sequence and molecular analyses}

Fourteen sequences (Bartonella sp. 1: MF580662MF580675) obtained in this study share over $99 \%$ similarity with $B$. schoenbuchensis isolated from moose blood from Sweden (GenBank: KB915628) and from human blood from France (GenBank: HG977196). Five sequences Bartonella sp. 2 (MF580657-MF580661) showed 94.6\% similarity with Bartonella sp. 3, and $94.4 \%$ with Bartonella sp. from Japanese sika deer from Japan (AB703149). Bartonella sp. 3 (MF580656) showed 99.7\% similarity with another samples isolated from Japanese sika deer from Wakayama Prefecture Japan (AB703149). Bartonella sp. 4. (MF580655) was $99,7 \%$ similar with Bartonella sp. isolated from Japanese sika deer (Cervus nippon centralis) from Nara Prefecture Japan (AB703146). These results are summarized in Table 2 and Additional file 1: Table S1.
Four $16 \mathrm{~S}$ rDNA sequences of deer ked were obtained, which were identical with Lipoptena cervi collected in the Czech Republic (AF322437). The sequences derived during this study were submitted to the GenBank database under the accession numbers MF541726-MF541729.

\section{Discussion}

Our findings indicate the presence of Bartonella species in deer keds (Lipoptena cervi) obtained from red deer (Cervus elaphus). Dehio et al. [16] noted that L. cervi appears to be a natural reservoir supporting the transmission of Bartonella schoenbuchensis. The largest group of isolates (Bartonella sp. 1) showed closed similarity with Bartonella schoenbuchensis. Our data indicate a high prevalence of Bartonella spp. A prevalence of $75.12 \%$ was recorded in the whole tested group, a result similar to global data; however, higher values were observed in Finland (90\%) and France (94\%) [14, 37].

Table 2 Bartonella spp. used in the phylogenetic analysis

\begin{tabular}{|c|c|c|c|c|}
\hline Isolate/sequence ID & Species & Host & Source & Country of isolation \\
\hline MF580662-MF580675 & Bartonella sp. 1 & Lipoptena cervi & whole body & Poland \\
\hline MF580657-MF580661 & Bartonella sp. 2 & Lipoptena cervi & whole body & Poland \\
\hline MF580656 & Bartonella sp. 3 & Lipoptena cervi & whole body & Poland \\
\hline MF580655 & Bartonella sp. 4 & Lipoptena cervi & whole body & Poland \\
\hline DQ356077 & Bartonella bovis & bovine & blood & Italy \\
\hline EF432062 & B. bovis & cow & valve (heart) & France \\
\hline KR733195 & B. bovis & cattle & blood & Malaysia \\
\hline KR733194 & B. bovis & cattle & blood & Malaysia \\
\hline KF218224 & B. bovis & water buffalo & blood & Thailand \\
\hline KF218220 & B. bovis & cattle & blood & Thailand \\
\hline KF218218 & B. bovis & cattle & blood & Guatemala \\
\hline KF218217 & B. bovis & cattle & blood & France \\
\hline HM167505 & Bartonella capreoli & moose & blood & USA \\
\hline AB703143 & B. capreoli & Japanese sika deer & blood & Japan \\
\hline AB703142 & B. capreoli & Japanese sika deer & blood & Japan \\
\hline AB703149 & Bartonella sp. & Japanese sika deer & blood & Japan \\
\hline AB703146 & Bartonella sp. & Japanese sika deer & blood & Japan \\
\hline AB703145 & Bartonella sp. & Japanese sika deer & blood & Japan \\
\hline KB915628 & Bartonella schoenbuchensis & moose & blood & Sweden \\
\hline KM215709 & Bartonella chomelii & cattle & blood & Spain \\
\hline KM215710 & Bartonella chomelii & cattle & blood & Spain \\
\hline JN646664 & Bartonella chomelii & cattle & blood & New Caledonia \\
\hline KJ909808 & Bartonella bovis & cattle & blood & Israel \\
\hline AB703148 & Bartonella sp. & Japanese sika deer & blood & Japan \\
\hline AB703144 & Bartonella sp. & Japanese sika deer & blood & Japan \\
\hline HG977196 & Bartonella schoenbuchensis & human & blood & France \\
\hline СР019789 & Bartonella schoenbuchensis & European roe deer & blood & Germany \\
\hline
\end{tabular}


To the best of our knowledge, the present paper is the first report in Poland to identify differences in the prevalence of Bartonella spp. infection in male and female deer keds. Females were more frequently infected than males; $86.67 \%$ of wingless females were infected by Bartonella, similar to a study from Hungary (76.0\%), while only $60.82 \%$ of wingless males were infected, also similar to a result in Hungary (58\%) [45].

The reason for such a difference in infection prevalence is not clear; however, it might be associated with the multiple bites needed for larvae production
(20-25 larvae per year) [34]. De Bruin et al. [45] suggested that Bartonella species are able to colonize or survive more efficiently as females than males, but the molecular mechanism for this remains unknown. The same authors [45] suggested that Bartonella spp. infection in female deer keds might lead to more female offspring than uninfected females, possibly resulting in the observed asymmetry in the female:male ratio of infected individuals.

By transmitting pathogens, Lipoptena cervi can be potentially dangerous for animals and humans. A study

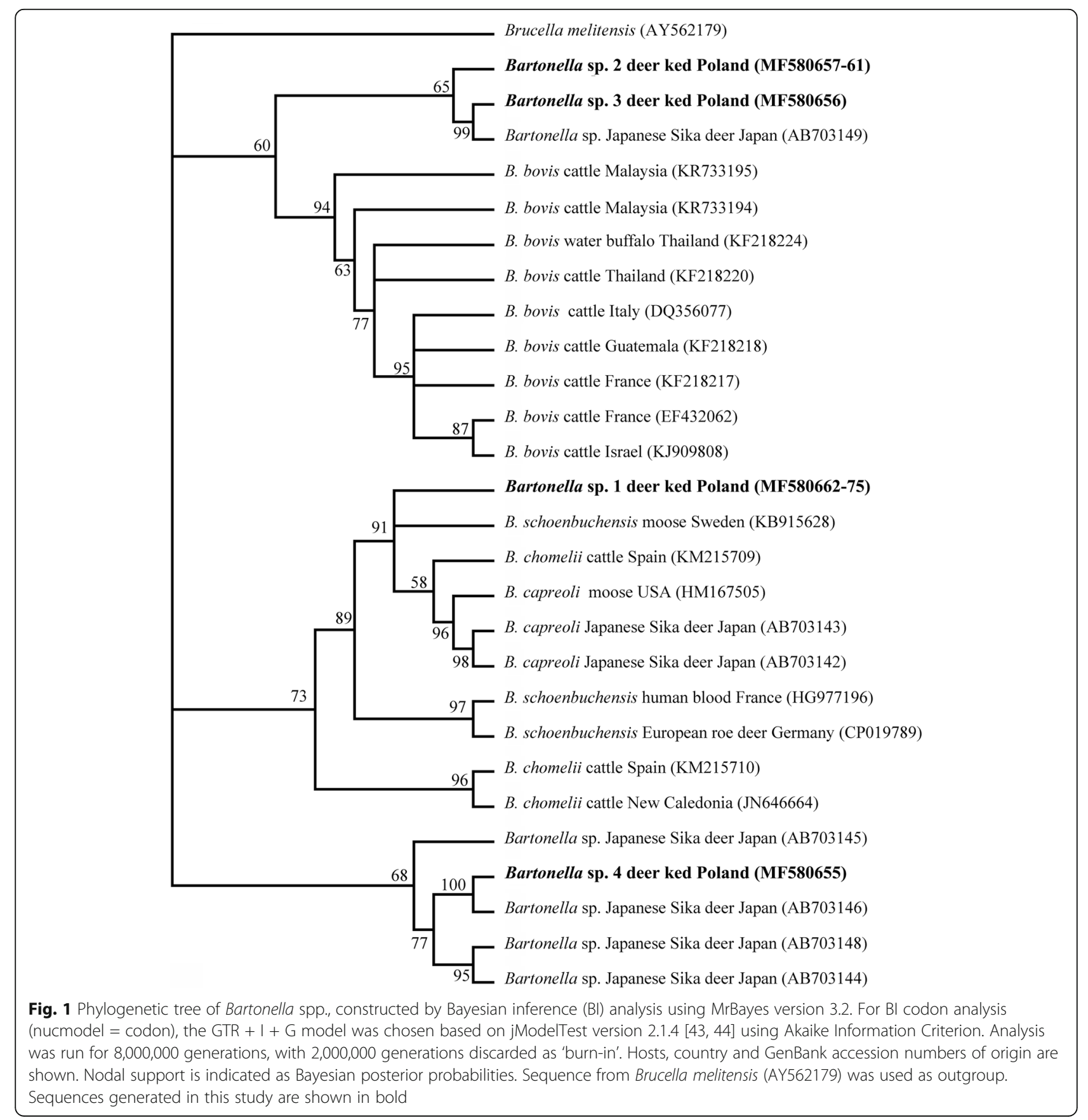


conducted in Finland found that $L$. cervi can transmit some pathogens by biting, and this is associated with hair-loss epizootics in moose [17]. Since the 1970s, in Finland an increasing number of cases of recurrent, and occasionally long-lasting, dermatitis associated with deer keds bites has been observed [46].

Fourteen of the sequences (Bartonella sp. 1, see Table 2.) isolated from deer keds demonstrated 99.2\% homology with a Bartonella schoenbuchensis sample isolated from moose in Sweden (KB915628). Bartonella schoenbuchensis could be found in vectors, such as $L$. cervi or L. mazamae, or in definitive hosts like cattle, wild ruminants and humans $[10$, $11,16]$. It is difficult to see how the relationship between $B$. schoenbuchensis and deer ectoparasites may relate to similar cases in humans. Lipoptena cervi has fed on humans under experimental conditions and in the natural environment $[18,47]$. As humans may be infected with $B$. schoenbuchensis during occasional biting by $L$. cervi, hunters, forestry workers and cross-country runners, among others, are at increased risk of infection [16]. Although $L$. cervi has not yet been definitively demonstrated to transmit $B$. schoenbuchensis through bites, it is possible that hunters are at risk to infection of Bartonella schoenbuchensis or Anaplasma phagocytophilum following exposure to deer blood [48].

In Massachusetts, a Bartonella sp. similar to B. schoenbuchensis has been found in Lipoptena mazamae [21], which suggests that Lipoptena species can extend the range of $B$. schoenbuchensis. Our phylogenetic analysis of the partial $r$ ro $B$ gene sequences found that our samples were in the same clade as other B. schoenbuchensis isolates from moose (KB915628) and human (HG977196). Bartonella schoenbuchensis (strain closely related to B. schoenbuchensis strain R1-86.6\%, gltA gene) was previously reported from roe deer (C. capreolus) in Poland [49].

Bartonella sp. 2 (5 isolates) and Bartonella sp. 3 (MF580656) demonstrated high similarity to sequences obtained from Japanese sika deer from Japan (AB703149, 94.6\% and 99.7\% similarity, respectively. These Bartonella isolates are related with the B. bovis clade in our phylogenetic analysis (Fig. 1).

Bartonella sp. 4 (MF580655) is very similar (99.7\%) to Bartonella sp. isolates collected from Japanese sika deer (AB703146, see Fig. 1) and in our phylogenetic analyses these isolates are associated with other Bartonella sp. isolates from Japanese sika deer and formed a distinct clade with Bartonella spp. isolated from Japanese sika deer. Probably "japanese" Bartonella isolates were introducted to Poland. This observation suggests that the strain of Bartonella sp. bacteria identified in the present study is derived from Japanese sika deer introduced to Europe by vectors to environment, indicating that this Asian strains could be spread by $L$. cervi to European red deer (Cervus elaphus).
Some Japanese Bartonella sp. samples, isolated from different prefectures, comprise a group distinct from other samples of Bartonella on GenBank; however, further testing is required utilizing other genes, including glt $A$ and $f t s Z$, to confirm whether they could be regarded as a distinct species.

\section{Conclusions}

Our data confirm that Bartonella spp. can be transmitted by deer ked in central Europe, and the prevalence of this pathogen is very high. In this area, Lipoptena cervi are infected by various species of the genus Bartonella.

\section{Additional files}

Additional file 1: Table S1. Pairwise comparison of partial (804 bp) mitochondrial gene $r p o B$ DNA and amino acid sequences variability among species/sequences of Bartonella used in phylogenetical analysis. Above diagonal: number of variable sites in the 268 amino acid gene $r p o B$ sequences. Below diagonal: number of variable sites in the nucleotides gene $r p o B$ sequences. The percentage of variable sites for each gene fragment between 2 species/sequences is given in parenthesis. Each species isolates/sequence information are provided in Table 2. (DOCX $23 \mathrm{~kb}$ )

\section{Acknowledgements}

The authors would like to express their gratitude to Marek Bogdaszewski, Head of the Research Station in Kosewo Górne (W. Stefański Institute of Parasitology), for enabling us to collect the samples from red deer.

\section{Funding}

No funding was received.

\section{Availability of data and materials}

The data supporting the conclusions of this article are included within the article and its additional file. The sequences were submitted to the GenBank database under the accession numbers MF580655-MF580675 (Uncultured Bartonella sp.) and MF541726-MF541729 (Lipoptena cervi).

\section{Authors' contributions}

TS planned and organized the study. JW and ŻSB collected samples. TS and JW extracted DNA. ZL performed PCR, sequencing and analyzed sequence data. TS, WJ and ZL drafted the manuscript, and wrote the final version together with GK. All authors read and approved the final manuscript.

Ethics approval and consent to participate

Not applicable.

Consent for publication

Not applicable.

\section{Competing interests}

The authors declare that they have no competing interests.

\section{Publisher's Note}

Springer Nature remains neutral with regard to jurisdictional claims in published maps and institutional affiliations.

Received: 21 April 2017 Accepted: 29 September 2017

Published online: 16 October 2017

References

1. Bai Y, Kandaurov A, Imnadze P, Kosoy M. Molecular survey of bacterial zoonotic agents in bats from the country of Georgia (Caucasus). PLoS One. 2017;12(1):e0171175 
2. Breitschwerdt EB, Kordick DL. Bartonella infection in animals: carriership, reservoir potential, pathogenicity, and zoonotic potential for human infection. Clin Microbiol Rev. 2000;13:428-38.

3. Karbowiak G, Rychlik L, Nowakowski W, Wita I. Natural infections of small mammals with blood parasites on the borderland of boreal and temperate forest zones. Acta Theriol. 2005;50:31-42.

4. Bai Y, Malania L, Alvarez Castillo D, Moran D, Boonmar S, Chanlun A, et al. Global distribution of Bartonella infection in domestic bovine and characterization of Bartonella bovis strain using multi-locus sequence typing. PLoS One. 2013;8(11):e80894

5. Sato S, Kabeya H, Yamazaki M, Takeno S, Suzuki K, Kobayashi S, et al. Prevalence and genetic diversity of Bartonella species in sika deer (Cervus nippon) in Japan. Comp Immunol Microbiol Infect Dis. 2012;35(6):575-81.

6. Boulouis HJ, Piemont Y. Bartonella birtlesii sp. nov., isolated from small mammals (Apodemus spp.). Int J Syst Evol Microbiol. 2000;50:1973-9.

7. Chomel B. Emerging bacterial zoonoses. Point Veterinaire. 2000;31:15-22.

8. Breitschwerdt EB, Maggi RG, Chomel BB, Lapin MR. Bartonellosis: an emerging infectious diseases of zoonotic importance to animal and humans being. J Vet Emerg Crit Care (San Antonio). 2010;20:8-30.

9. Maggi RG, Mozayeni BR, Pultorak EL, Hegarty BC, Bradley JM, Correa M, Breitschwerdt EB. Bartonella spp. bacteremia and rheumatic symptoms in patient from Lyme disease-endemic region. Emerg Infect Dis. 2012;18:783-91.

10. Dehio C, Lanz C, Pohl R, Behrens P, Bermond D, Piemont Y, Pelz K, Sander A. Bartonella schoenbuchii sp. nov., isolated from the blood of wild roe deer. Int J Syst Evol Microbiol. 2001;51:1557-65.

11. Rolain JM, Rousset E, La Scola B, Duquesnel R, Raoult D. Bartonella schoenbuchensis isolated from the blood of a French cow. Ann NY Acad Sci. 2003;990:236-8.

12. Vayssier-Taussat $M$, Moutailler $S$, Fèmènia $F$, Raymond $P$, Croce $O$, La Scola $B$, et al. Identification of novel zoonotic activity of Bartonella spp., France. Emerg Infect Dis. 2016;22:457-62.

13. Müller A, Reiter M, Schötta AM, Stockinger $H$, Stanek $G$. Detection of Bartonella spp. in Ixodes ricinus ticks and Bartonella seroprevalence in human population. Ticks Tick Borne Dis. 2016;7:763-7.

14. Halos L, Jamal T, Maillard R, Girard B, Guillot J, Chomel B, et al. Role of Hippoboscidae flies as potential vector of Bartonella spp. infecting wild domestic ruminants. Appl Environ Microbiol. 2004;70(10):6302-5.

15. Sytykiewicz H, Karbowiak G, Werszko J, Czerniewicz P, Sprawka I, Mitrus J. Molecular screening for Bartonella henselae and Borrelia burgdorferi sensu lato co-existence within Ixodes ricinus populations in central and eastern parts of Poland. Ann Agric Environ Med. 2012;19(3):451-6.

16. Dehio C, Sauder U, Hiestand R. Isolation of Bartonella schoenbuchensis in Lipoptena cervi, a blood-sucking arthropod causing deer ked dermatitis. J Clin Microbiol. 2004;42(11):5320-3.

17. Madslien K, Ytrehus B, Vikøren T, Malmsten J, Isaksen K, Hygen HO, Solberg EJ. Hair-loss epizootic in moose (Alces alces) associated with massive deer ked (Lipoptena cervi) infestation. J Wild Dis. 2011:47(4):893-906.

18. Bequaert JC. Monograph of the Melophaginae of ked-flies of sheep, goats, deer and antelopes (Diptera, Hippoboscidae). Bull Brooklyn Ent Soc. 1942;22:1-220.

19. Maa TCA. synopsis of the Lipopteninae (Diptera: Hippoboscidae). J Med Entomol. 1965;2:233-48.

20. Valimaki P, Madslien K, Malmsten J, Harkonen I, Harkonen S, Kaitala A, et al. Fennoscandian distribution of an important parasite of cervids, the deer ked (Lipoptena cervi), revisted. Parasitol Res. 2010;107:117-25.

21. Reeves WK, Nelder MP, Cobb KD, Dasch GA. Bartonella spp. in deer keds, Lipoptena mazamae (Diptera: Hippoboscidae), from Georgia and South Carolina, USA. J Wildl Dis. 2006;42(2):391-6.

22. Kettle DS. Medical and veterinary entomology. London, UK: Croom Helm. 1984:285-92.

23. Haigh JC, Mackintosh C, Griffin F. Viral, parasitic and prion diseases of farmed deer and bison. Rev Sci Tech (Int Off Epizoot). 2002;21:219.

24. Pérez-Espona S, Pemberton JM, Putman R. Red and sika deer in the British Isles, current management issues and management policy. Mamm Biol. 2009;74:247-62.

25. Sokół R, Gałęcki R. Prevalence of keds on city dogs in central Poland. Med Vet Entomol. 2017;31:114-6.

26. Kowal J, Nosal P, Rościszewska M, Matysek M. [New records of Lipoptena fortisetosa MAA, 1965 (Diptera: Hippoboscidae) in Poland.] Dipteron. 2009; 25:27-9 (In Polish).

27. Kowal J, Nosal P, Kornaś S, Wajdzik M, Matysek M, Basiaga M, Różnorodność i. znaczenie muchówek z rodziny narzępikowatych - pasożytów jeleniowatych. Med Weter. 2016;72:745-9.
28. Matsumoto K, Berrada ZL, Klinger E, Goethert HK, Telford SR. Molecular detection of Bartonella schoenbuchensis from ectoparasites of deer in Massachusetts. Vector Borne Zoonotic Dis. 2008;8(4):549-54.

29. Chistyakov AF. Skin lesions in people due to bites of Lipoptena cervi. Vestn Dermatol Venerol. 1968;42:59-62.

30. Rantanen T, Reuanala T, Vuojolahti P, Hackman W. Presistent pruritic papules from deer ked bites. Acta Derm Venereol. 1982;62:307-11.

31. Haarlov N. Life cycle and distribution pattern of Lipoptena cervi (L.) (Dipt. Hippobosc.) on Danish deer. Oikos. 1964;15:93-129.

32. Madslien K, Ytrehus B, Vilijugrein H, Solberg EJ, Braten KR, Mysterud AA. factors affecting deer ked (Lipoptena cervi) prevalence and intensity in moose (Alces alces) in Norway. Parasit Vectors. 2012;5:251.

33. Mysterud A, Madslien $\mathrm{K}$, Herland A, Viljugrein $H_{1}$ Ytrehus B. Phenology of deer ked (Lipoptena cervi) host-seeking flight activity and its relationship with prevailing autumn weather. Parasit Vectors. 2016:9:95.

34. Borowiec L. [Wpleszczowate Hippoboscidae. Klucze do oznaczania owadów Polski.] Część XXVIII/77 77. Wrocław 1984 (In Polish).

35. Kortet R, Härkönen L, Hokkanen P, Härkönen S, Kaitala A, Kaunisto S, et al. Experiments on the ectoparasitic deer ked that often attacks humans; preferences for body parts, colour and temperature. Bull Entomol Res. 2010;100:279-85.

36. Buss M, Case L, Kearney B, Coleman C, Henning JD. Detection of Lyme disease and anaplasmosis pathogens via PCR in Pennsylvania deer ked. J Vector Ecol. 2016:41:292-4.

37. Korhonen EM, Pèrez Vera C, Pulliainen AT, Sironen T, Aaltonen K, Kortet R, et al. Molecular detection of Bartonella spp. in deer ked pupae, adult keds and moose blood in Finland. Epidemiol Infect. 2014;143:578-85.

38. Samuel W, Trainer D. Lipoptena mazamae Rondani, 1878 (Diptera: Hippoboscidae) on white-tailed deer in southern Texas. J Med Entomol. 1972:9:104-6.

39. Adamska M. Infestation of game animals from north-western Poland by common tick (Ixodes ricinus). Wiadi Parazytol. 2008;54:31-6.

40. Paziewska A, Harris PD, Zwolińska L, Bajer A, Siński E. Recombination within and between species of the alpha proteobacterium Bartonella infecting rodents. Microb Ecol. 2011;61:134-45.

41. Renesto P, Gouvernet J, Drancourt M, Roux V, Raoult D. Use of rpoB analysis for detection and identification of Bartonella species. J Clin Microbiol. 2001; 3(2):430-7.

42. Huelsenbeck JP, Ronquist F. MRBAYES: Bayesian inference of phylogenetic trees. Bioinformatics. 2001;17:754-5.

43. Guindon S, Gascuel OA. simple, fast, and accurate algorithm to estimate large phylogenies by maximum likelihood. Syst Biol. 2003;52:696-704.

44. Darriba D, Taboada GL, Doallo R, Posada D. jModelTest 2: more models, new heuristics and paralel computing. Nat Methods. 2012;9(8):772.

45. de Bruin A, van Leeuwen AD, Jahfari S, Takken W, Földvári M, Dremmel L, et al. Vertical transmission of Bartonella schoenbuchensis in Lipoptena cervi. Parasit Vectors. 2015;8:176

46. Härkönen S, Laine M, Vornanen M, Reunala T. Deer ked (Lipoptena cervi ) dermatitis in humans - an increasing nuisance in Finland. Alces. 2009;45:73-9.

47. Starzyk J. Strzyżak sarni, Lipoptena cervi (L.) (Diptera, Hippoboscidae) pasożyt zewnętrzny parzystokopytnych. Prz. Zool. 1975;17:446-8.

48. Telford SR III, Bakken JS, Dumler JS. Risk for acquiring human granulocytic ehrlichiosis: exposure to deer blood or deer ticks? Clin Infect Dis. 1997;24:531-3.

49. Welc-Falęciak R, Werszko J, Cydzik K, Bajer A, Michalik J, Behnke JM. Coinfection and genetic diversity of tick-borne pathogens in roe deer from Poland. Vector Borne Zoonotic Dis. 2013:13:277-88. 